\title{
MANUFACTURING AND EVALUATION OF A FERTILIZATION AND CULTIVATION DUAL PURPOSE UNIT FOR SMALL FARMS
}

\author{
Fouda, T.Z* , A.A,Derbala ${ }^{* *}$, A.H,Elmetwalli ${ }^{* * *}$, \\ S.Shlaby ${ }^{* * * *}$ and, Amina.A, $\mathbf{E}^{* * * * * *}$
}

\begin{abstract}
The experimental work was carried out through agricultural Summer season of 2014 at the experimental farm Research Station, Gemmiza; Gharbiya governorate to manufacturing and evaluation of a fertilization and cultivation dual purpose unit for fiber crops(Kenaf and Roselle) under small farms conditions. The manufactured dual purpose unit performance was studied as a function of change in machine forward speed(2.2, 2.8,3.4 and $4 \mathrm{Km} / \mathrm{h})$ and fertilizing rates(30,45 and 60 Kg.N.fed $\left.{ }^{-1}\right)$.at average of soil moisture content $22 \%$.Dual purpose unit was evaluated in terms of effective field capacity, ,field efficiency, fuel consumption, power and energy requirements and. The experiment results reveled that the manufactured double acting unit decreased energy and increased effective field capacity and field efficiency with using machine forward speed $2.2 \mathrm{Km} / \mathrm{h}$.fertilizing rate $45 \mathrm{Kg}^{\mathrm{N}} \mathrm{N}$.fed ${ }^{-1}$, and soil moisture content was $22 \%$ d.b.
\end{abstract}

\section{INTRODUCTION}

ertilizer is any organic or inorganic materials used in improving
soil properties and fertility by increasing the total contents of
important nutrients of agricultural crops to increase production. Singh, (2001). developed three row rotary weeder to study the rotary weeding performance and compared with the traditional practices of weeding by wheel hand hoe and by chemical control. The results showed that the weeder had problem while working in a clay soil. Plant damage in case of rotary weeder was $2.46 \%$ whereas it was nil in case of wheel hand hoe and chemical control.

\footnotetext{
*Prof. of Agric .Eng .Dept ., Fac. of Ag., Tanta. Univ. **Associate Professor in Agric. Eng. Dept., Fac. of Ag., Tanta. Univ. ****Lecturer of Agric. Eng. Dept., Fac. of Ag., Tanta. Univ. ****Associate researcher of Agric Eng Gmiza research center . ******Postgraduate of Agric. Eng. Dept., Fac. of Ag., Tanta. Univ.
} 
The cost of weeding by rotary weeder was Rs 283.16 /ha as compared to wheel hand hoe (Rs 174.16/ha) and chemical control (Rs. 617.10/ha) which is $36 \%$ more than wheel hand hoe and $72 \%$ less than chemical control. Grain yield obtained for wheel hand hoe, rotary weeder and chemical control was comparable. King et al. (2002). pointed out that much of the variability in root responses to $\mathrm{N}$ availability could be due to differences in methodology (including discrimination of root classes), natural soil fertility, and vegetation life history. Pannu et al. (2002) evaluated a self-propelled, engine operated power weeder, which has a diesel engine of $3.8 \mathrm{hp} \mathrm{(3600} \mathrm{rpm),} \mathrm{as} \mathrm{a} \mathrm{power} \mathrm{source.} \mathrm{The} \mathrm{weeder} \mathrm{has} \mathrm{L-}$ shaped blades. This weeder was found to be suitable for weeding in wider row crops like maize, cotton, sugarcane etc. The moisture content of the soil at the time of evaluation was 17-18\%. The depth of operation ranged from $4-7 \mathrm{~cm}$ (avg. $6.8 \mathrm{~cm}$ ). The machine was operated at an average forward speed of $1.64 \mathrm{~km} / \mathrm{h}$. The weeding efficiency of $88 \%$ was obtained with the machine. Krishnan et al. (2004) developed a $5.4 \mathrm{~kW}$ diesel engine operated power weeder for weeding and intercultural in sugarcane crop. The machine was capable of weeding $1 \mathrm{ha} / \mathrm{day}$. Sufficient soil mulch was produced for better crop growth. The effective field capacity and weeding efficiency was observed to be $0.082 \mathrm{ha} / \mathrm{h}$ and 96\% respectively. The cost of weeding comes out to Rs 770/ha. Aziz and Ansell (2004) stated that, the fiber crops have existed in human society since the beginning of time. History shows that humans collected raw materials from the wild to use as ropes or textiles. Later, societies learned to cultivate such crops. Natural fiber crops are among the earliest known cultivated plants and humans have continued to domesticate these crops over time. Fiber crop varieties have been extensively developed through breeding and selection according to societies' needs and values. Abdul Khalil et al (2010) studied that Kenaf (Hibiscus cannabinus L.) is a traditional, third world crop after wood and bamboo that is poised to be introduced as a new annually renewable source of industrial purpose in the so-called developed economies. Kenaf is a warm-season annual fiber crop growing in temperate and tropical areas. It is related to cotton, okra, and hibiscus due to systematic. It is a fibrous plant, consisting of an inner core fiber (75-60\%), which produces low quality pulp, and an outer bast 
fiber (25-40\%), which produces high quality pulp, in the stem. The plant grows to a height of 2.7-3.6 mand is harvested for its stalks, from which the fiber is extracted. Mohan and Kanny, (2012) stated that cellulosic fibers produced from plant stems, such as Kenaf, sisal, hemp, flax, jute, and ramie, are a viable reinforcement in composite materials, and there has been tremendous increase in a research interests regarding their applications over the past few years, possibly due to their biodegradability and low cost.

\section{The main objectives of this study are to:}

1-Manufactuer cultivating and fertilizing unit mounted on walking tractor suitable for small farms.

2- Optimize some different parameters affecting the performance of dual purpose unit and minimize energy requirements.

\section{MATERIALS AND METHODS}

Experiment was carried out through Summer season of 2014 at the experimental farm of Gemmiza Research Station, Gharbiya governorate to evaluate the performance of fertilizing and weeding double acting unit to suit a small farms for fiber crops (Kenaf and Roselle). Soil mechanical analysis and some soil characteristics are shown in table (1).

Table (1): Some soil characteristics of the experimental soil.

\begin{tabular}{|c|c|c|c|c|c|c|c|}
\hline \multirow{2}{*}{$\begin{array}{l}\text { Soil } \\
\text { texture }\end{array}$} & \multirow{2}{*}{$\begin{array}{l}\text { Bulk } \\
\text { Density, } \\
\text { gm|cm }{ }^{3}\end{array}$} & \multirow{2}{*}{$\begin{array}{l}\text { Porosit } \\
\mathbf{y}\end{array}$} & \multirow[t]{2}{*}{$\mathbf{p H}$} & \multirow[t]{2}{*}{ Ec } & \multicolumn{3}{|c|}{ NPK, p.p.m } \\
\hline & & & & & $\mathbf{N}$ & $\mathbf{P}$ & $\mathbf{K}$ \\
\hline $\begin{array}{l}\text { Clay } \\
\text { lest }\end{array}$ & $\begin{array}{l}1.17 \mathrm{gm} / \mathrm{cm}- \\
3\end{array}$ & 55.849 & 7.5 & 2.1dsm-1 & 53.2 & 6.1 & 273 \\
\hline
\end{tabular}

\section{1-MATERIALS}

\subsection{Fiber crops:}

Tow types of fiber crops were used in this study, Roselle (Hibiscuses Sabdariffa) variety Egyptian Roselle and Kenaf (Hibiscus Cannabinus) variety Giza3.

\subsection{Dual purpose unit.}

A local manufactured combination cultivating and fertilizing unit suitable for small farms consists of the following parts as shown in fig2.

1-Frame and wheels: The main fixed frame is made of iron sheet steel. With dimensions of $150 \mathrm{~cm}$ length, $36 \mathrm{~cm}$ width and $18 \mathrm{~cm}$ height. The 
frame includes elements to fix the weeding and fertilizing unit, also a hanged joint was constructed to attached the manufactured machine

Table (2). Physical properties of Kenaf and Roselle seeds.

\begin{tabular}{|l|l|l|}
\hline Physical properties & Kenaf seeds & Roselle seeds \\
\hline Length ,mm & 4.12 & 4.24 \\
\hline Width ,mm & 2.58 & 3 \\
\hline Thickness ,mm & 1.44 & 1.06 \\
\hline Volume ,mm ${ }^{3}$ & 15.306 & 13.48 \\
\hline Mass of $1000 \mathrm{seeds}, \mathrm{g}$ & 20 & 21.5 \\
\hline Bulk density $\mathrm{mg} / \mathrm{mm}^{3}$ & 1.3 & 1.59 \\
\hline
\end{tabular}

1.2.The power source: four strokes- diesel engine Walking tractorSH151-1 of(11.03kW) was used as a power source.

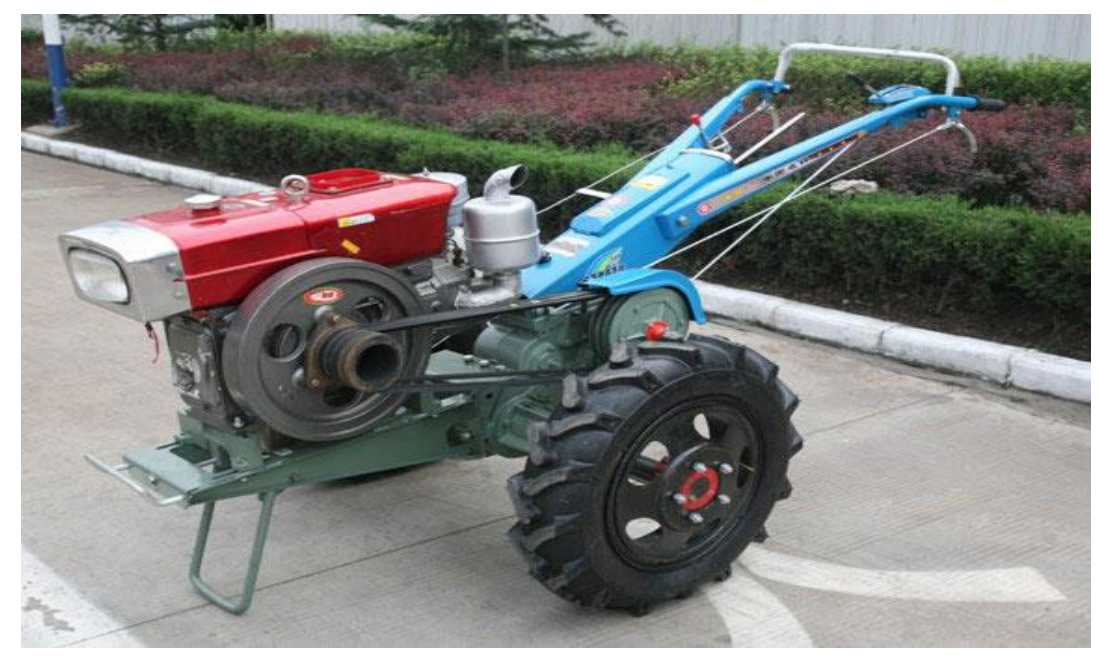

Fig (1) Walking tractor--SH151-1

the walking tractor. It was carried by two ground wheels with $70 \mathrm{~cm}$ diameter.

2- Cultivating unit: Cultivating unit consists of three beams and three shares every single share was fixed in one beam with the ability of changing the distance between beams and the depth of share in the soil.

3- Fertilizing unit: fertilizing unit consists of two fertilizer hoppers, feed mechanism, fertilizing tubes, furrow openers and machine wheels as shown in fig 3. 
-Feeding mechanism: it was consists of three parts arranged from up to down as shown in fig 4:

1-Upper disc: it has aperture semicircular peripheral with a curved shape, the fertilizer follow from it to the following disc.2- Circular disc: it has eight cells with a trapezoidal shape .3- Down disc

-Transmission system: the motion was transmitted from the machine wheel to the fertilizing unit through out three groups of tooth wheels; each group was six toothed wheels $(14,16,18,20,24$ and 28 teeth) and was fixed together with one piece which could be used to change the speed by putting the transmission chain between group and another according to permitted speed.

-Furrow fertilizers openers: two furrow openers were fixed in two beams and later fixed in the main frame to facilitate the changing of distance between beam and depth of furrow fertilizer opener.

-Covering device: the covering device was composed of two ground wheels.

\section{2- METHODS:-}

The experimental area was about $720 \mathrm{~m}^{2}$ which was devided into two equal plots $\left(360 \mathrm{~m}^{2}\right.$ ) .The first plot was cultivated with Kenaf (Hibiscus cannabinus) crop, Varity Giza3 with row spacing $60 \mathrm{~cm}$ and distance between seeds in the same row $10 \mathrm{~cm}$.while the second plot was cultivated with Roselle (Hibiscus Sabdariffa) crop, Varity Egyptian Roselle with row spacing $60 \mathrm{~cm}$ and distance between seeds in the same row $10 \mathrm{~cm}$.

\subsection{Experimental condition.}

Field experiment were carried out to find the effect of four different parameters on the manufactured machine performance mainly under using tow types of fiber crops Roselle and Kenaf plant

\section{Parameters}

1- Four different machine forward speeds $(2.2,2.8,3.4$ and $4 \mathrm{Km} / \mathrm{h})$.

2-Three fertilizing rates $(30,45$, and $60 \mathrm{Kg} . \mathrm{N} / \mathrm{fed})$.

3-Three different plant population (20,30, and 40 plant $/ \mathrm{m} 2)$.

\subsection{Measurements and determinations.}

Performance evaluation of the manufactured machine was based on the following indicators: 
-Soil moisture content: The soil moisture content was determined as dry basis by using an electric oven adjusted at $105^{\circ} \mathrm{c}$ for 24 hours . Soil

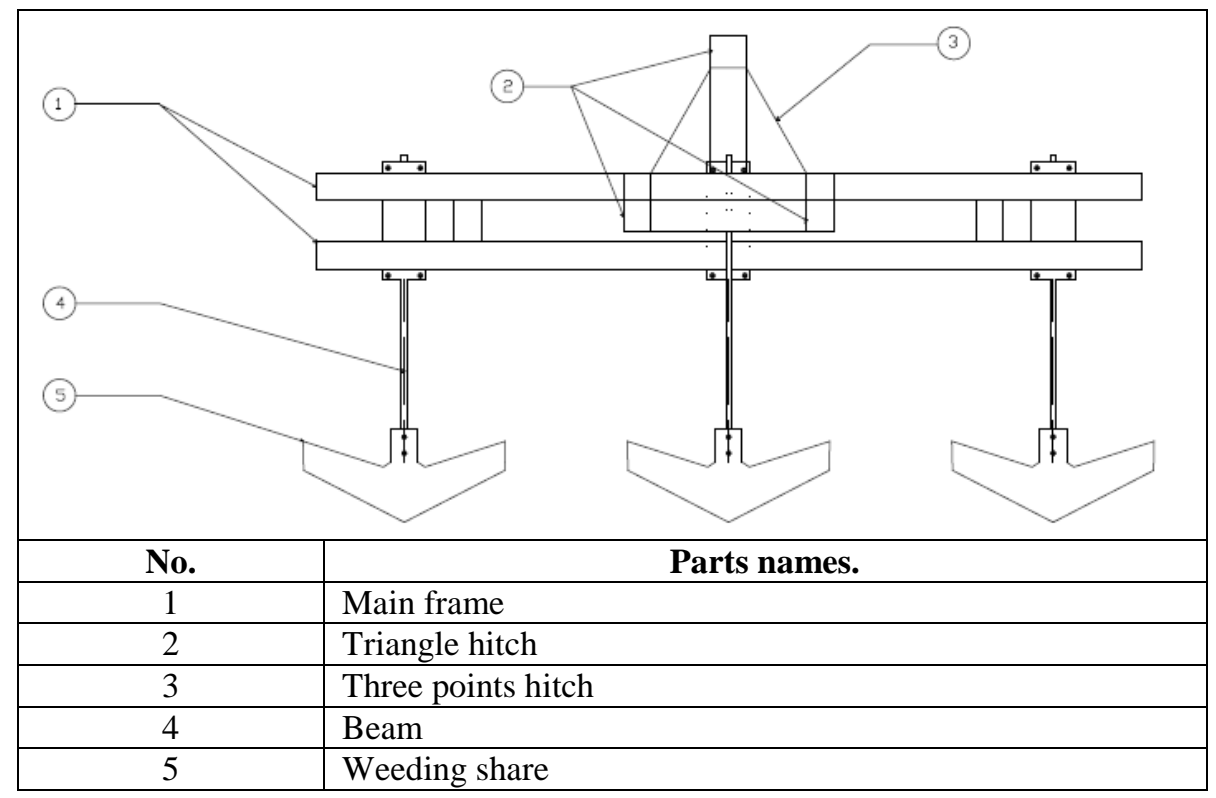

Fig: 2. The manufactured cultivating unit.

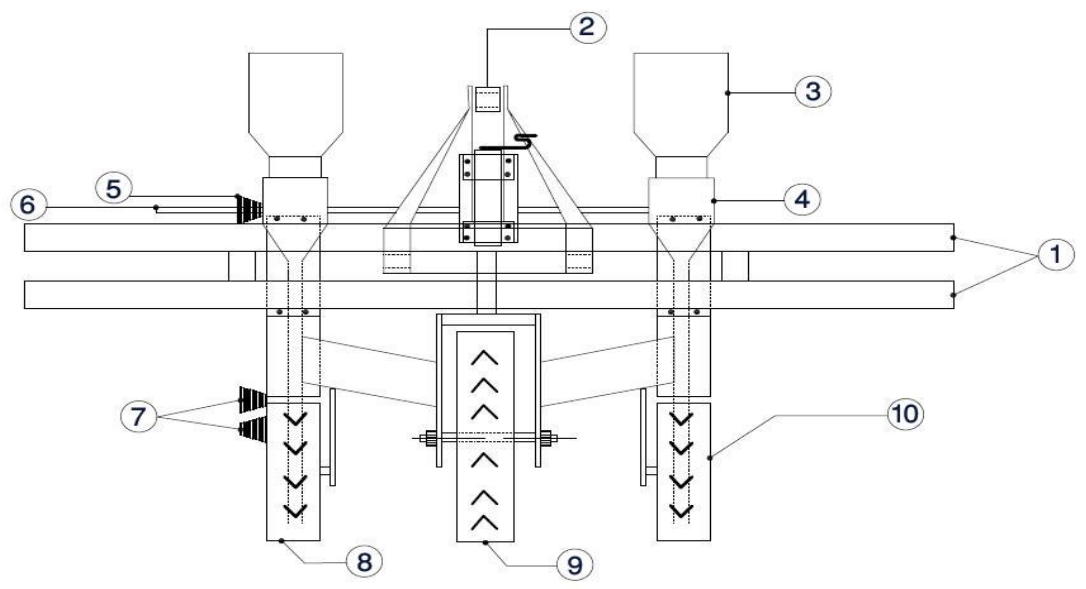

\begin{tabular}{|l|l|l|l|}
\hline No. & Part name. & No. & Part name. \\
\hline 1 & Main frame & 6 & Transmission connect shaft. \\
\hline 2 & Hitch point & 7 & Transmission system \\
\hline 3 & Fertilizer hopper & 8 & Ground wheel to transmission unit \\
\hline 4 & Feeding unit & 9 & Drive wheel \\
\hline 5 & Group of tooth wheels & 10 & Ground wheel for machine balance \\
\hline
\end{tabular}

Fig: 3. The manufactured fertilizing unit. 


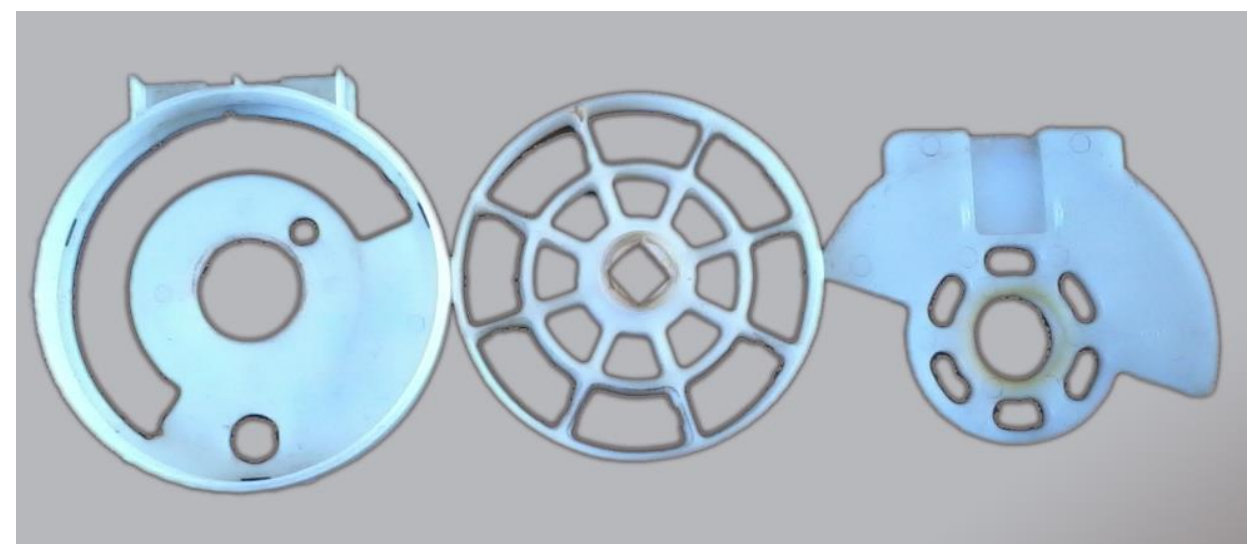

Fig4. Feed mechanism adjustment

samples were taken from different locations and by screw auger. The moisture content was calculated on dry bases by using following equation:

\section{$\mathrm{Mc}=(\mathrm{Sw}-\mathrm{Sd}) / \mathrm{Sd} \times 100$}

Where:-Mc $=$ Soil moisture content on dry basis, $\%, \mathrm{Sw}=\mathrm{Wet}$ soil mass, g. and $\mathrm{Sd}=$ Dry soil mass, g.

\section{-Fuel consumption:}

Fuel consumption $=\frac{\text { Fuel consumption, } \mathrm{ml}}{\text { Time }, \mathrm{sec} .} \times 3.6, \mathrm{~L} / \mathrm{h}$

\section{Field efficiency:}

The theoretical field capacity was calculated by using the following formula (Kepner et al., 1982):

$\mathrm{Tfc}=\frac{\mathrm{V} \times \mathrm{W}}{4.2}, \mathrm{fed} / \mathrm{h}$.

Where: Tfc $=$ Theoretical field capacity, fed, $\mathrm{V}=$ Average implement forward speeds, $\mathrm{km} / \mathrm{h}$; and $\mathrm{W}=$ The working width of implement, $\mathrm{m}$ The Effective field capacity (Efc) was determined as follows:

$$
\mathrm{Efc}=\frac{1}{\mathbf{T}}, \mathrm{fed} / \mathbf{h}
$$

Where:- Efc = effective field capacity, fed/h, and $\mathrm{T}=$ The total time.

Field efficiency is the ratio of effective field capacity to theoretical field capacity and it gives an indication of the time lost in field and the failure to utilize the full working width of the machine. The field efficiency 
( $\eta f$ ) was calculated by using the following formula: $\eta \mathrm{f}=\frac{\text { Efc }}{\text { Tfc }} \times 100, \%$

Where:- $\eta \mathrm{f}=$ Field efficiency, $\%$, Efc $=$ Effective field capacity, fed $/ \mathrm{h}$ and $\mathrm{Tfc}=$ Theoretical field capacity, fed/h.

-Power requirements: the required power was calculated by using the following formula (Embaby, 1985).

$\mathrm{EP}=\mathrm{Fc} \times\left(\frac{1}{3600}\right) \rho_{\mathrm{f}} \times \mathrm{L} . \mathrm{C} . \mathrm{V} \times 427 \times \frac{1}{75} \times \frac{1}{1.36} \eta \mathrm{th} \times \eta \mathrm{m},(\mathrm{kW})$ Where:-

$\mathrm{Fc}=$ Fuel consumption, $1 / \mathrm{h}, \rho_{\mathrm{f}}=$ Density of the fuel $(0.73 \mathrm{~kg} / \mathrm{l}$ for gasoline fuel), L.C.V. = Lower calorific value of fuel $(11030 \mathrm{k} \mathrm{cal} / \mathrm{kg}$ for gasoline fuel), $427=$ Thermo - mechanical equivalent, $\mathrm{kg} . \mathrm{m} / \mathrm{k}$ cal, $\eta$ th $=$ Thermal efficiency of engine (35\% for gasoline engine), and $\eta \mathrm{m}=$ Mechanical efficiency of engine ( $85 \%$ for gasoline engine).

- Energy requirements: The energy requirements was calculated as follows:

Energy requirements, $k W . h / f e d .=\frac{\text { Required power, } k W}{\text { Effective field capacity, fed } / h}$

\section{RESULTS AND DISCUSSION}

The discussion will cover the obtained results under the following heads:

\section{Cultivation and fertilization unit manufacturing.}

Cultivation and fertilization unit mounted on walking tractor was manufactured and evaluated for four forward speeds (2.2, 2.8 and 3.4, and $4 \mathrm{~km} / \mathrm{h}$ ) at three levels of adding fertilizer (30, 45 and $60 \mathrm{~kg} . \mathrm{N} / \mathrm{fed})$ at three plant population $(20,30$, and 40 plant $/ \mathrm{m} 2)$ at two different fibers crops (Kenaf and Roselle) at average of soil moisture content of $22 \%$ and depth of weeding and fertilizing was $5 \mathrm{~cm}$.

\section{1- Effect of weeding and fertilizing unit forward speed on fuel consumption.}

Fig. 5. Shows the effect of variation forward speed at $22 \%$ soil moisture content, it was clear that fuel consumption increased by increasing forward speed. Through out cultivating process the minimum obtained 
value of fuel consumption $2.7 \mathrm{~L} / \mathrm{h}$ was obtained with the forward speed $2.2 \mathrm{Km} / \mathrm{h}$. While the maximum obtained value of fuel consumption 4.7 $\mathrm{L} / \mathrm{h}$ was obtained with the forward speed $4 \mathrm{Km} / \mathrm{h}$. Mean while through out fertilizing process the minimum obtained value of fuel consumption $2.6 \mathrm{~L} / \mathrm{h}$ was obtained with the forward speed $2.2 \mathrm{Km} / \mathrm{h}$. The maximum obtained value of fuel consumption $4.5 \mathrm{~L} / \mathrm{h}$ was obtained with the forward speed $4 \mathrm{Km} / \mathrm{h}$ under three level of nitrogen fertilization for two types of fiber crops.

\section{2- Effect of weeding and fertilizing unit forward speed on Engine power.}

Fig.6. Illustrated the effect of weeding and fertilizing unit forward speed on Engine power required $(\mathrm{kW})$. Obtained results shows the Engine power was increased by increasing the developed machine forward speed $(\mathrm{Km} / \mathrm{h})$. Through out cultivating process the minimum Engine power of $6.7 \mathrm{~kW}$ was obtained with the forward speed $2.2 \mathrm{Km} / \mathrm{h}$. While, the maximum Engine power of $11.3 \mathrm{~kW}$ was obtained with the forward speed $4 \mathrm{Km} / \mathrm{h}$. Meanwhile through out fertilizing process the minimum Engine power $6.1 \mathrm{~kW}$ was obtained with the forward speed $2.2 \mathrm{Km} / \mathrm{h}$. Meanwhile, the maximum Engine power of $10.8 \mathrm{~kW}$ was obtained with the forward speed $4 \mathrm{Km} / \mathrm{h}$ under three levels of $\mathrm{N}$-Fertilization.

\section{3- Effect of weeding and fertilizing unit forward speed on Energy required.}

Fig.7 Illustrate the effect of cultivating and fertilizing unit forward speed on Energy required ( $\mathrm{kW} / \mathrm{h} / \mathrm{fed})$. Obtained results shows the Engine power was increased by increasing fertilizing unit forward speed $(\mathrm{Km} / \mathrm{h})$. Through out cultivating process the minimum Energy required of 0.033 $(\mathrm{kW} / \mathrm{h} / \mathrm{fed}$ was obtained with the forward speed $2.2 \mathrm{Km} / \mathrm{h}$. While the maximum Energy required of $0.042(\mathrm{~kW} / \mathrm{h} / \mathrm{fed}$ was obtained with the forward speed $4 \mathrm{Km} / \mathrm{h}$ for the three levels of N-Fertilization. Meanwhile, through out fertilizing process the minimum Energy required of 0.092 $(\mathrm{kW} / \mathrm{h} /$ fed was obtained with the forward speed $2.2 \mathrm{Km} / \mathrm{h}$. and, the maximum Energy required of $0.12(\mathrm{~kW} / \mathrm{h} / \mathrm{fed}$ was obtained with the forward speed $4 \mathrm{Km} / \mathrm{h}$ under three levels of N-Fertilization. 


\section{4- Effect of cultivating and fertilizing unit forward speed on theoretical field capacity.}

Fig.8. Shows the effect cultivating and fertilizing of forward speed on theoretical field capacity. Obtained results show a remarkable rise in theoretical field capacity by increasing the forward speed. Obtained results showed that through out cultivating process theoretical field capacity increased as a result of increasing forward speed. The minimum value of Theoretical field capacity $0.86 \mathrm{Fed} / \mathrm{h}$ was obtained with Forward speed $2.2 \mathrm{Km} / \mathrm{h}$, on the other hand The maximum value of Theoretical field capacity $1.5 \mathrm{Fed} / \mathrm{h}$ was obtained with Forward speed $4 \mathrm{Km} / \mathrm{h}$ under three levels of Plant population. While through out fertilizing process the minimum obtained value of theoretical field capacity $0.81 \mathrm{fed} / \mathrm{h}$ was obtained with the forward speed $2.2 \mathrm{Km} / \mathrm{h}$. While the maximum obtained value of theoretical field capacity $1.4 \mathrm{fed} / \mathrm{h}$ was obtained with the forward speed $4 \mathrm{Km} / \mathrm{h}$ under three levels of nitrogen fertilization.

\section{5- Effect of cultivating and fertilizing unit forward speed on Effective field capacity.}

Fig.9. Shows the effect cultivating and fertilizing of forward speed on Effective field capacity. Obtained results shows through out cultivating process the Effective field capacity was increased by increasing the forward speed. The minimum obtained value of the Effective field capacity $78 \mathrm{fed} / \mathrm{h}$ was obtained with the forward speed $2.2 \mathrm{Km} / \mathrm{h}$. While the maximum obtained value of the Effective field capacity $113 \mathrm{fed} / \mathrm{h}$ was obtained with the forward speed $4 \mathrm{Km} / \mathrm{h}$. and through out fertilizing process the minimum obtained value of the Effective field capacity 66 $\mathrm{fed} / \mathrm{h}$ was obtained with the forward speed $2.2 \mathrm{Km} / \mathrm{h}$. While the maximum obtained value of the Effective field capacity $99 \mathrm{fed} / \mathrm{h}$ was obtained with the forward speed $4 \mathrm{Km} / \mathrm{h}$ under three levels of nitrogen fertilization.

\section{6- Effect of cultivating and fertilizing unit forward speed on Field efficiency.}

Fig.10. Illustrate the effect of cultivating and fertilizing unit forward speed on Field efficiency. Obtained results shows through out cultivating process there was a remarkable drop in the field efficiency. The maximum field efficiency of $94 \%$ was obtained with the forward speed 
$2.2 \mathrm{Km} / \mathrm{h}$. and , the minimum field efficiency of $84 \%$ was obtained with the forward speed $4 \mathrm{Km} / \mathrm{h}$. While through out fertilizing process the maximum field efficiency of $82 \%$ was obtained with the forward speed $2.2 \mathrm{Km} / \mathrm{h}$. Meanwhile, the minimum field efficiency of $69 \%$ was obtained with the forward speed $4 \mathrm{Km} / \mathrm{h}$ under three levels of $\mathrm{N}$ Fertilization.

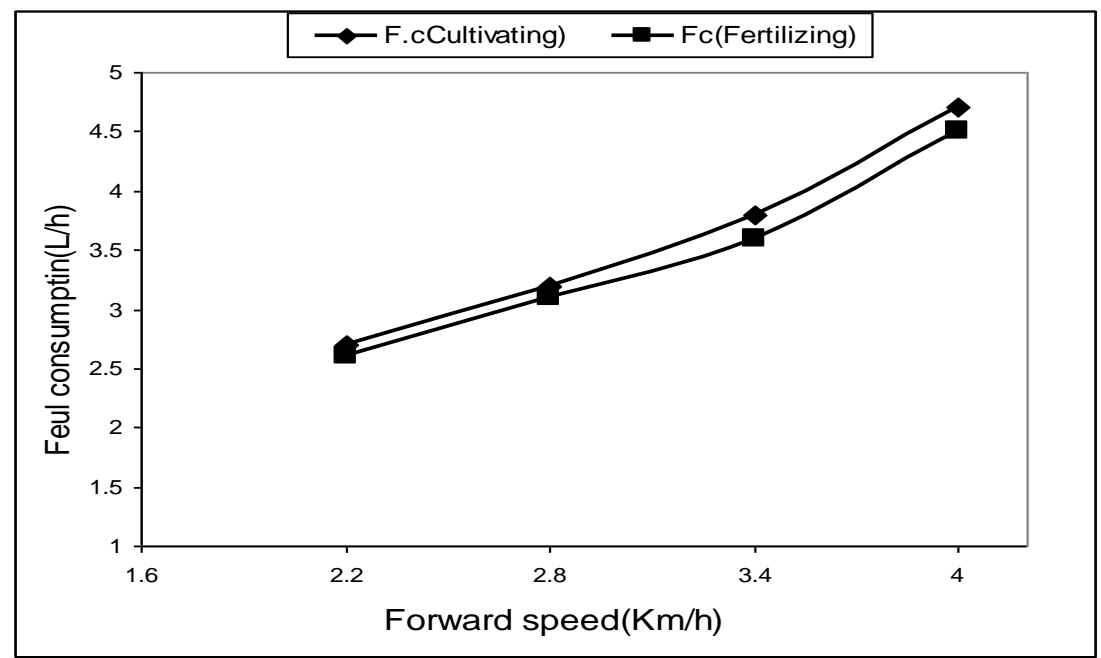

Fig. 5 : Relationship between forward speed and Fuel consumption under three different levels of $\mathrm{N}$-fertilization` at constant soil moisture content $22 \%$, and depth $5 \mathrm{~cm}$.

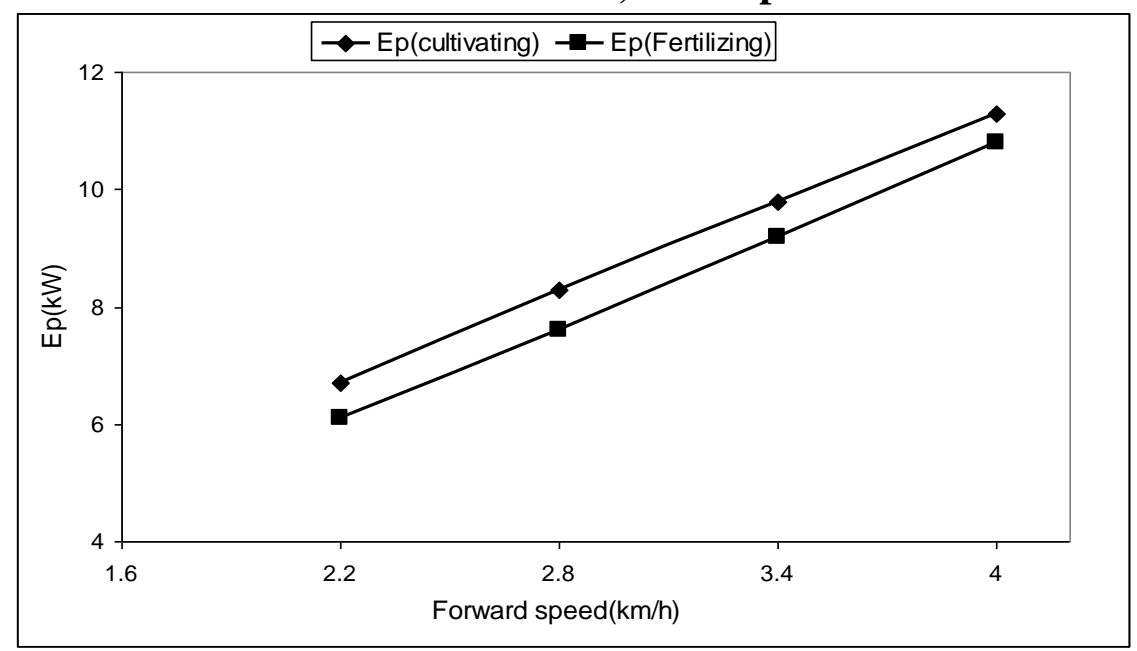

Fig.6:Relationship between forward speed and Engine power under three different levels of $\mathbf{N}$-fertilization at constant soil moisture content $22 \%$, and depth $5 \mathrm{~cm}$. 


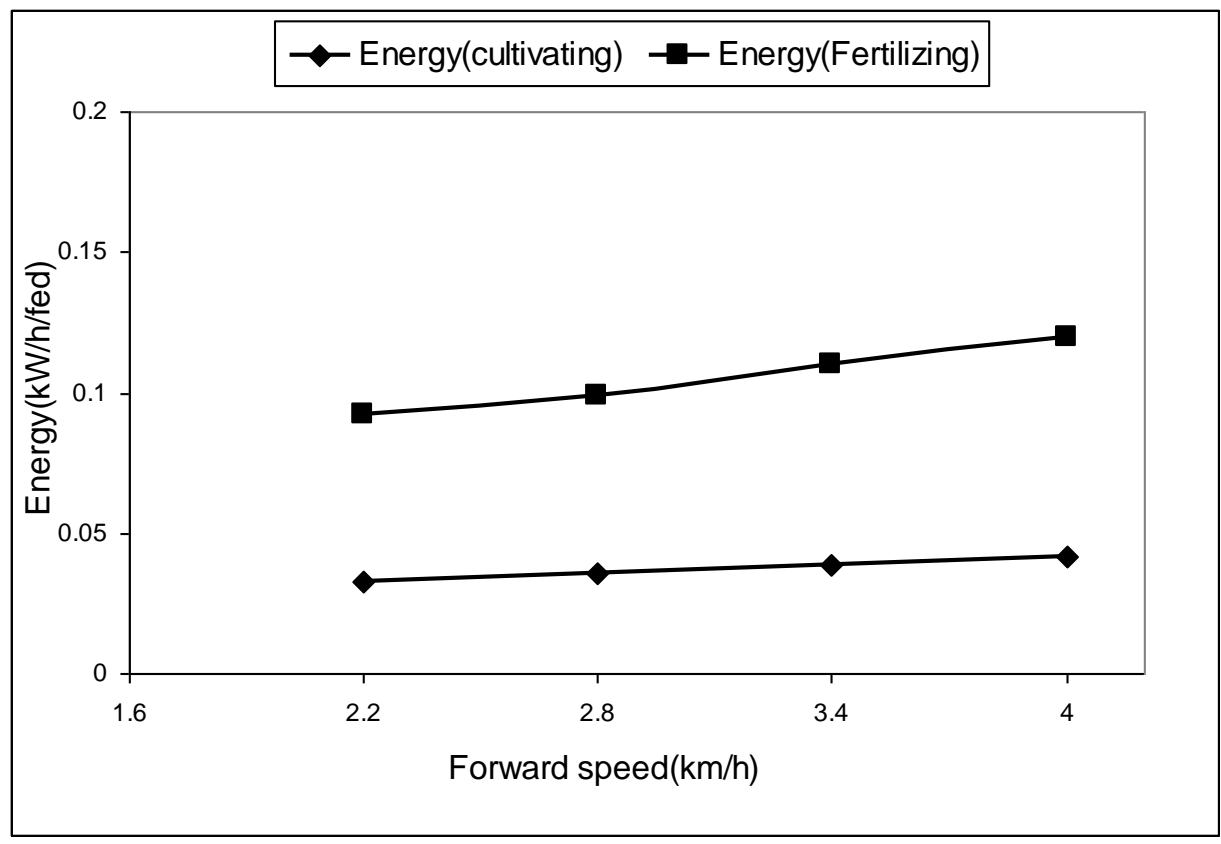

Fig.7: Relationship between forward speed and required energy under three different levels of $\mathrm{N}$-fertilization at constant soil moisture content $22 \%$, and depth $5 \mathrm{~cm}$.

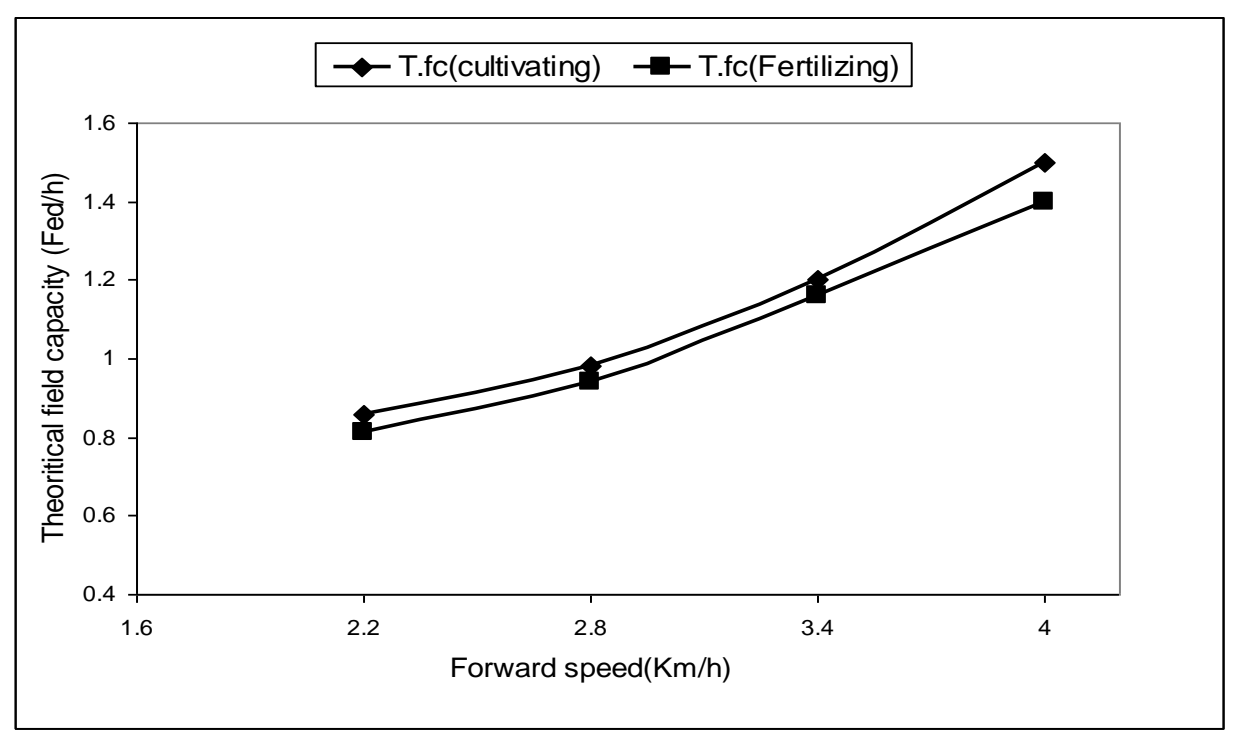

Fig. 8: Relationship between Forward speed and Theoretical field capacity under three different levels of $\mathrm{N}$-fertilization at constant soil moisture content $22 \%$, and depth $5 \mathrm{~cm}$. 


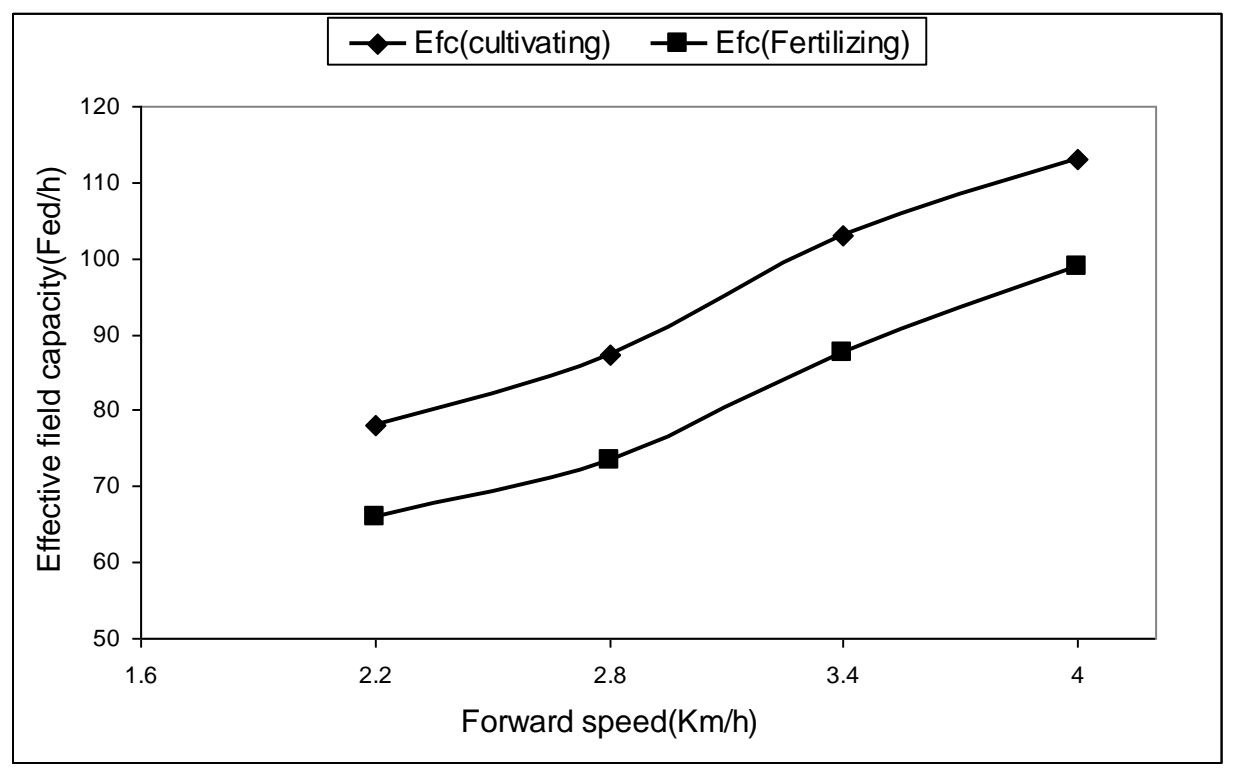

Fig.9: Relationship between forward speed and Effective field capacity under three different levels of $\mathbf{N}$-fertilization at constant soil moisture content $22 \%$ and depth $5 \mathrm{~cm}$.

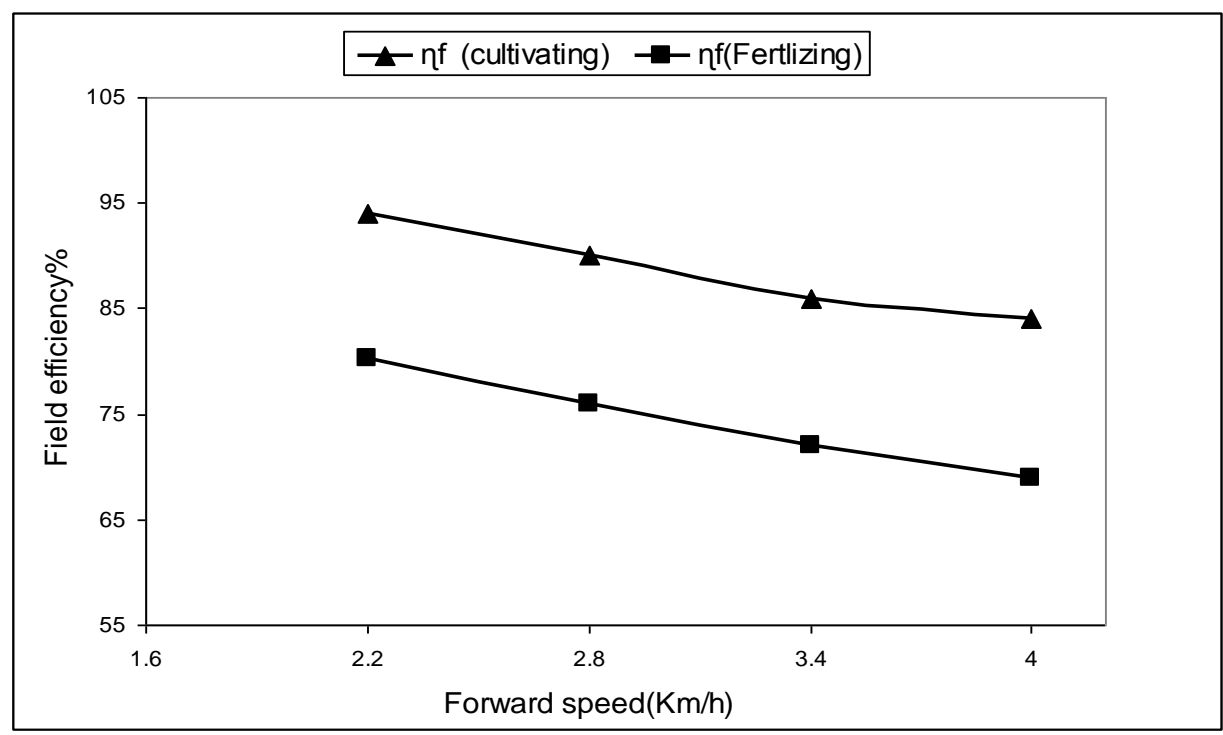

Fig.10: Relationship between forward speed $(\mathrm{Km} / \mathrm{h})$ and Field efficiency (Fed/h) under three different levels of $\mathbf{N}$-fertilization at constant soil moisture content $22 \%$, and depth $5 \mathrm{~cm}$. 


\section{CONCLUSION}

When using manufactured double acting unit in the small farm decreased energy and increased effective field capacity and field efficiency for using fertilizing and weeding process at forward speed $2.2 \mathrm{Km} / \mathrm{h}$ and soil moisture content $20 \%$

\section{REFERENCES}

Abdul Khalil, H.P.S., Ireana Yusra, A.F., Bhat, A.H., Jawaid, M., 2010. Cell wall ultrastructure, anatomy, lignin distribution, and chemical composition of Malaysian cultivated kenaf fibre. Ind. Crop. Prod. 31 (1), 113-121.

Aziz SH and Ansell MP. (2004) The effect of alkalization and fiber alignment on the mechanical and thermal properties of kenaf and hemp bast fiber composites: part 1-polyester resin matrix.Compos Sci Technol;64:1219-30.

Embaby, A. T. (1985) A comparison of different mechanization systems of cereal crop production. M.Sc. Thesis. Fac. of Agric., Cairo University, Egypt.

Kepner, R.A.; R. Bainer and E.L. Barger (1982). Principles of farm machinery. The AVI publishing Co. Inc. West Port, Connecticut.

Krishnan, A., V. M. Duraiswamy; R. Karunanithi and R. Kavitha (2004 c) Frontline demonstration on power weeder (sugarcane crop). All India Co-ordinated Research Project progress report, TNAU Coimbatore.

Mohan, T.P., Kanny, K., (2012) Chemical treatment of sisal fiber using alkali and claymethod. Composites: Part A 43, 1989-1998.

Pannu, C. J. S., A. Dixit., I. K. Garg and B. Dogra (2002) Feasibility evaluation of rotary power weeder on wider row crops like cotton, maize, sunflower, soybean etc. Annual Report, Punjab Agricultural University, Ludhiana: 18-26. PAU, India. 
Singh, R. (2001) Studies on rotary weeder in wheat crop. M. Tech thesis, Punjab Agricultural University, Ludhiana, India.

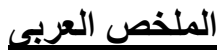

تصنيع وتقييم وحدة ثنائية الغزض للتسميد والعزيق للمزارع الصغيره

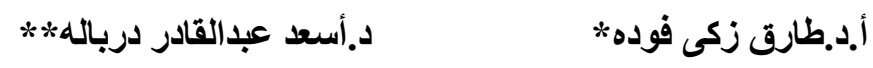

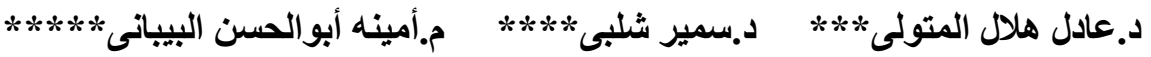

نظر التفتت الحياز ات الزر اعبه في مصروخاصة بأر اضى الدلتا فقد أدى ذلك إلى صعوبة تطبيق

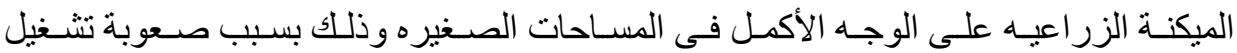
الجرارات والآلات الزر اعيه كبيرة الحجم في نهايات الحقل. وفى هذا البحث تم تصميم وتقيهيم وحدة عزيق وتسميد لخدمة محصولين من أهم محاصيل الألياف فى العالم (التيل و الكركديـه).

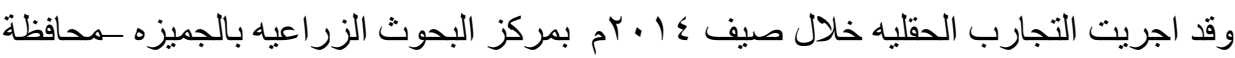
الغربيه .

وكاتت أهداف الار اسة كما يلي:اـتطبيق عمليات العزيق و التسميد فى المساحات الصغيره بواسطة الوحدة المصنعه. بـ در اسة عو امل التشغيل للآلة المصنعه بهدف الوصول الى القيم المثلى للتشغيل rـ تقليل التكاليف و الطاقه المستهلكة في عمليات العزيق و التسميد لكي تناسب ظروف المساحات الصغيره.

ثم تم تقييم أداء الأله بأخذ المؤشرات التاليه فى الاعتبار

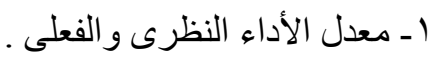
ب الكفاءه الحقليه. بـكفاءة الأله فى توزيع السماد وكذللك كفاءتها فى عملية العريق. ع ـمعدل استهلاك الوقود 0ـ القدره و الطاقه المستهلكه.

*أستاذ الزهنسه الزراعيه ـكلية الزراعهجهامعة طنطا.

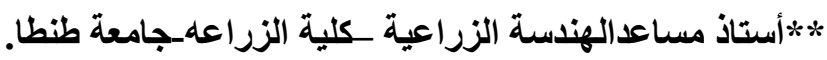
***مدرس الهندة الزراعية كلية الزراعهاعجامعة طنطا.

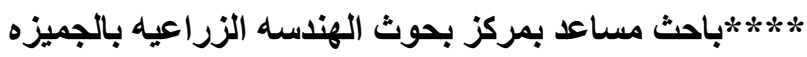

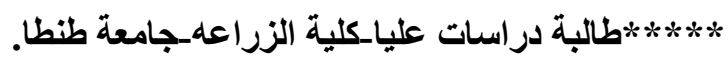


وقد تم التوصل الى النتائج التاليه من خلال التجارب الحقليه:

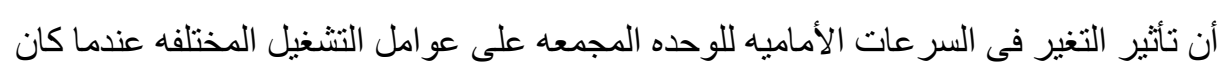
متوسط نسبة الرطوبه للتربه r \% مانت كالتالى:-

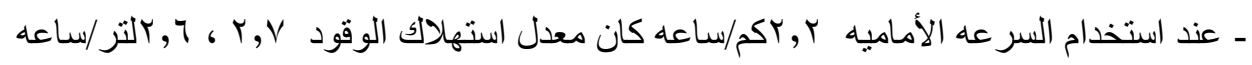

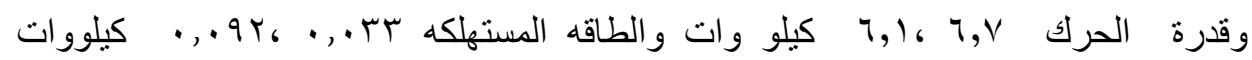

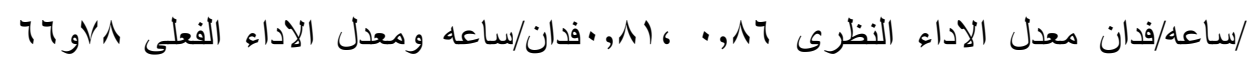

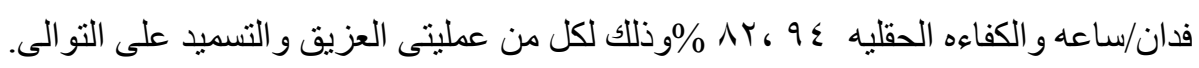

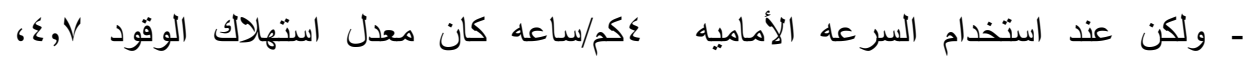

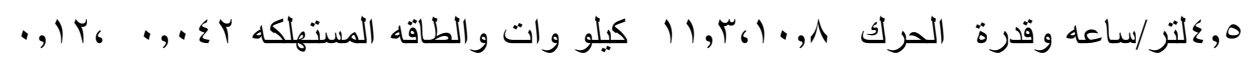

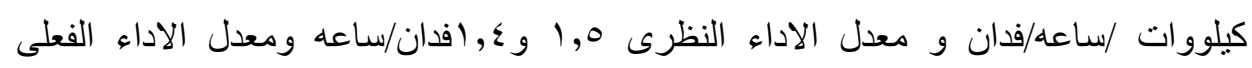

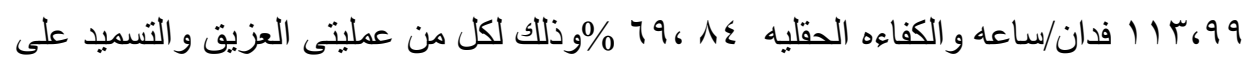
التو الى. 